\title{
Study on Frankenstein from the Perspective of New Historicism
}

\author{
Ruimin Xu, Yafen Huang \\ Nanchang Institute of Science \& Technology, Nanchang, 330108, China
}

Keywords: new historicism; historical context; romanticism; ideology

\begin{abstract}
New historicism is a kind of backwash of literary ontology thoughts like formalism and structuralism. It not only argues that we should put historical study into the literature research, but also points out there isn't exist the relationship of "outlook" and "background" between literature and history, for they interact and influent each other. This paper analyzes the novel from the perspective of new historicism, reconstructs the historical context, and then points out that the novel how to reflect the historical context ---- romanticism, and how to express people's rich inner feelings, the complex relation between man and nature, and the influence of the ideology at that time in the novel.
\end{abstract}

\section{The Introduction of the Novel}

"Frankenstein" is the classic work of Mary Shelley, which is praised as the most outstanding gothic novel and the world's first science fiction by western literary circle ${ }^{[1]}$. Mary Shelley is the second wife of Shelley, a famous British romantic poet (1797-1851). In 1816, Mary, Percy Shelley, and Byron agreed to write a ghost story. Frankenstein, the novel was born in this way. The novel tells a story of creating man by human being. Frankenstein was a scientist, he created a monster through a lot of tests, the monster also had a kind heart, and he was ready to help others, so he wanted to be accepted by others. But because he was very ugly, so he was not accepted by the human society, everyone refused him, and chased him. He yearned for love and happiness, so he asked his creator, frankenstein, to make another person like him, but his require was rejected. So he began to retaliate against humanity temerariously, and at last he died with his creator ${ }^{[2]}$. After the book was published in 1818, immediately it caused a sensation, the figure of the monster which was created by Mary Shelley and Frankenstein became a household name. We can analyze the novel in terms of new historicism in order to have a deeper understanding of the novel.

\section{Analysis on the Novel from the Perspective of New Historicism}

New Historicism came into being in 1980s, though it had already emerged at the end of the 1970s when it was used as a new critical method in the field of Renaissance research. Stephen Greenblatt from the University of California firstly put forward the term of "New Historicism" in Genre in $1982^{[3]}$.

Louis Montrose provided a more precise definition for new historicism, which was the two famous dictums of "the texuality of history" and "the historicity of the texts". "the historicity of the texts" means that all "texts" are the products of specific historical culture and political economy. The reading of any text is not purely objective, it should be understood under the specific historical environment, "text" itself is an important part of history; " the texuality of history" refers that there is no difference between the literary text and non-literary text. The historical documents is just the document literature by forefathers, they also have the narrative fiction like literary "text" ${ }^{\text {"[4] }}$. In this opinion, the boundary between history and literature is abolished, and literature researches are placed in a grand historical narrative context.

\subsection{Analysis on the novel from the historical context}

First of all, the new historicism emphasizes the reconstruction of the historical context of literary texts, that is, the historical context of literary creation ${ }^{[5]}$. As early as the 19th century, French critic 
Danner explicitly pointed out that literary creation should not be isolated, it should be subjected to the three key elements: race, environment and age. Danner said that in order to understand a piece of artwork, a group of artists, you must correctly assume the spirit and customs of the age which they belong to. This is the final explanation of artwork, and the root cause why culture decide everything ${ }^{[6]}$. The new historicism criticism attaches great importance to search for the historical context of literary texts, that is, the social and cultural environment that literature form.

Frankenstein was written by Mary Shelley in 1816 and published in 1818. Social cultural environment at this time was in the end of the Enlightenment. During the prevalence of romantic period, the romantic literature in the process of its development has formed some characteristics. One of the most outstanding and the most essential characteristics is its subjectivity, that is, laying particular stress on the subjective spirit, and expressing strong personal feelings. Romantic literatures generally don't like to truthfully describe the real life, but prefer for author's subjective world, individual feels about things in one's heart. Romanticists claim that Enlightenment thinkers change the vivid human being into a machine without soul, the rational rule makes people separate their feeling, and disturbs the normal expression of human nature, especially the reveal of people's passion under the pressure of rational has become "indifference" and insensitive.

\subsection{Analysis on the novel from romanticism}

The romanticists thought that man should restore the true nature of man to be a complete man, and human beings should fully express their feelings ${ }^{[7]}$. In the book of Frankenstein, there are many descriptions of the emotions of human characters. When frankenstein was about to create a monster, the author described frankenstein's excited feeling like that "I've been addicted to this passion, like a hurricane, pushing me forward, and no one can describe me complex mood at this moment. In my opinion, the difference between life and death is only a fiction by people, and I must first break through the boundary and inject the light of life into the dark shadow. There will be a new specie of creatures who makes me the creator, and calls me the holy spirit, and many blessed and lucky dogs will gratitude my favor. No father in the world is more powerful than I am to ask children to be grateful" ${ }^{[2]}$. When Justin was framed for killing William, Frankenstein regretted that he created a monster by himself and the monster killed his relatives, that kind of fear and despair was around him, "I chocked back the profound grief of mind and turned around to see Elizabeth, she was speechless, and immersed in deep sorrow. This was the sin that I had made, and my father was in the pain. We had been filled with this laughter, but now it is a desolate home, I caused it all, what a crime! Weep, you wretches, and this is not your last tears, and you shall see the coffin again, and weep again. You frankenstein, the prodigal son, your flesh and blood, your beloved friend in his early years, would rather run out of every drop of blood for you, but his heart was like dead ashes, and he can no longer feel the happiness in the world, unless his joy can also be reflected in your loved ones' face. He is willing to pray to god, to bless you, he is wiling to serve you for life, but the result is to make you cry and cry, and tears flow endlessly. If the ruthless fate is over, if the god of destruction is no longer close to our family from now on, if there is no grave become the home of the tortured souls, he will be overjoyed, and feel that the worldly happiness is just at his side" [2] These detailed descriptions reflect frankenstein's rich inner world. His excitement, bitterness, and hatred are incisively and vividly displayed in front of people. Of course we can't miss the another protagonist in the novel - the monster who created by frankenstein, Frankenstein said the monster is a machine without blood and meat. We actually found that monster is like human beings based on the research of the novel. The monster is full of emotions. At the beginning of the monster being created, he could also feel cold and pain, and he could cry, when he saw a bright moon, his heart was filled with joy, when he found how to use fire to warming, he also felt excited, when he saw that his neighbor Della had a happy family, and Felix and Sophie enjoyed the joy of love, he began to envy, he also wondered why he did not have father, mother, family, lovers, he felt so lonely and he tried to be close to his neighbor in order to let them accept him, and he wanted to have his own friends to get a little warm, but his neighbor was frighten to move. The monster began to have an anger at this time, he burned his neighbor's house, and then left that place. 


\subsection{Analysis on the novel from ideology}

The New Historicism also attaches great importance to the ideological differences in literary texts. In any age, the dominant ideology must exclude other ideologies to maintain its own rule. The New historicism puts forward that we should research the relationship between literature and industry, democracy, class, art, culture, religion, etc from different views. Now, Let's analyze the relationship between literature and religion. We know that the main ideology at that time was to oppose the feudalism and the shackles of religion. Since the industrial revolution, people have begun to forge ahead and develop science and technology. Frankenstein created people, which was a great challenge to traditional religion. Yet when frankenstein created people, he also felt doubts and guilty. The novel said that with regard for blasphemy, frankenstein dabbled in the dark and damp catacombs. Frankenstein created a monster, perhaps for the motivation was not pure, he wanted to be the God, so he was subjected to be punished. The monster whom he created to put him into the abyss of pain again and again, and constantly hurt his relatives, finally frankenstein also believed that God punished him for the monster, and his misfortune blasphemous was the result of blasphemy. In another part, it maintained the religious rule at that time, people can win against God. Frankenstein suffered such a miserable fate, which push people under the control of religion again. It also illustrated the contradiction between Mary's traditional religious ideas and social demands for scientific and technological progress.

\section{Conclusion}

Through analyzing the novel of frankenstein from the perspective of new historicism, we find a different frankenstein. As people often say "there are one thousand readers, there are one thousand Hamlets". Through the perspective of new historicism to reconstruct the historical context, we know the darkness of society, the ruling class and religious oppression at that time, people were longing for freedom and liberation, and people welcomed and feared the emerging science and technology. We need to magnify our views, the works of each era and the history when the works are created are interchangeable and intertexted. Therefore, we should look at the relationship between literature and language, mythology, religion, etc from multiple perspectives ${ }^{[7]}$.

\section{References}

[1] Liu Xinming. Comment on Frankenstein. [J]. Foreign Literature studies,2001:(01)

[2] Mary Shelley. Frankenstein [M]. world publishing press,2013.

[3] Greenblatt. Introduction: The Forms of Power [J]. Genre 7, 1982.

[4] Tyson, Lois. 'New Historicism' Selective Readings in 20th Century Western Critical Theory [C]. Zhang Zhongzai. Beijing: Foreign Language Teaching and Research Press,2002.

[5] Chen Rong. New Historicism. The keywords of western literary criticism. [M]. Foreign Language Teaching and Research Press, 2004.

[6] H Danner. Philosophy of art. [M]. Anhui Literature and Art Publishing House,1998.

[7] Wang Xianling. The Criticism of New Historicism. [M]. Central China Normal University Press, 2000. 